\title{
Leaves of Mauritia flexuosa L. f. (Arecaceae) is effective in vitro and in vivo in the control of Haemonchus contortus
}

\author{
Folhas de Mauritia flexuosa L. f. (Arecaceae) tem eficácia, in vitro e in vivo no controle de \\ Haemonchus contortus
}

Hojas de Mauritia flexuosa L. f. (Arecaceae) es eficaz in vitro e in vivo en el control de Haemonchus contortus

\begin{abstract}
In this study we evaluated the potential of Mauritia flexuosa leaves in the egg hatching and larval development inhibition and for reduction of egg count of this nematode in sheep feces. The leaves of this palm were collected and dehydrated for the production of aqueous and ethanolic extracts with and without tannins. Gas chromatography analysis indicated the presence of fifteen and ten major compounds in the aqueous and ethanolic extracts, respectively, and both showed catechin peaks. The total of condensed tannins for leaves of Mauritia flexuosa was $33.23 \% \pm 2$. Aqueous and ethanolic extracts showed $100 \%$ anthelmintic activity to inhibit hatchability at $75 \mathrm{mg} / \mathrm{ml}$. The inhibitory concentrations LC 90 for aqueous and ethanolic extracts were, respectively, 21.8 and $8.5 \mathrm{mg} / \mathrm{ml}$. The dehydrated leaves powder of $M$. flexuosa at $\geq 152.08 \mathrm{mg} / \mathrm{g}$ of coproculture presented efficiencies greater than $80 \%$ for inhibition of larval development. The in vivo administration of aqueous extract at $62.1 \mathrm{mg} / \mathrm{kg}$ PC promoted anti-helminthic efficacy of $54.57 \%$ and, after 14 days, no clinical signs of toxicity and clinical changes were observed in the treated lambs, indicating potential of this extract for the control alternative of haemonchosis.
\end{abstract}

Keywords: Anti-helminthic; Buriti; Cerrado; Gas chromatography; Gastrointestinal nematodes; Sheep. 


\begin{abstract}
Resumo
Neste estudo avaliou-se o potencial das folhas de Mauritia flexuosa na inibição da eclosão e do desenvolvimento larval e redução da contagem de ovos deste nematódeo em fezes de ovinos. As folhas dessa palmeira foram coletadas e desidratadas para a produção dos extratos aquosos e etanólicos com e sem taninos. A análise por cromatografia gasosa indicou a presença de 15 e 10 compostos principais nos extratos aquoso e etanólico, respectivamente, e ambos mostraram picos de catequina. O total de taninos condensados para folhas de Mauritia flexuosa foi de 33,23\% \pm 2 . Os extratos aquoso e etanólico mostraram $100 \%$ de atividade anti-helmíntica para inibir a eclodibilidade a $75 \mathrm{mg} / \mathrm{ml}$. As concentrações inibitórias CL90 para os extratos aquosos e etanólicos foram, respectivamente, 21,8 e 8,5 mg / ml. O pó de folhas desidratadas de $M$. flexuosa a $\geq 152,08 \mathrm{mg} / \mathrm{g}$ de coprocultura apresentou eficácias superiores a $80 \%$ para inibição do desenvolvimento larval. A administração in vivo do extrato aquoso a $62,1 \mathrm{mg} / \mathrm{kg}$ de PC promoveu eficácia anti-helmíntica de $54,57 \%$ e, após 14 dias, não foram observados sinais clínicos de toxicidade e alterações clínicas nos cordeiros tratados, indicando potencial deste extrato para o controle alternativo de hemoncose.
\end{abstract}

Palavras-chave: Anti-helmíntico; Buriti; Cerrado; Cromatografia em fase gasosa; Nematódeos gastrointestinais; Carneiro.

\title{
Resumen
}

En este estudio evaluamos el potencial de las hojas de Mauritia flexuosa en la inhibición de la eclosión de huevos y el desarrollo larvario y para la reducción del recuento de huevos de este nematodo en heces de ovejas. Las hojas de esta palma fueron recolectadas y deshidratadas para la producción de extractos acuosos y etanólicos con y sin taninos. El análisis de cromatografía de gases indicó la presencia de quince y diez compuestos principales en los extractos acuoso y etanólico, respectivamente, y ambos mostraron picos de catequina. El total de taninos condensados para las hojas de Mauritia flexuosa fue $33.23 \% \pm 2$. Los extractos acuosos y etanólicos mostraron una actividad antihelmíntica del $100 \%$ para inhibir la eclosión a $75 \mathrm{mg} / \mathrm{ml}$. Las concentraciones inhibidoras CL90 para extractos acuosos y etanólicos fueron, respectivamente, 21,8 y $8,5 \mathrm{mg} / \mathrm{ml}$. El polvo de hojas deshidratadas de M. flexuosa a $\geq 152.08 \mathrm{mg} / \mathrm{g}$ de coprocultivo presentó eficiencias superiores al $80 \%$ para la inhibición del desarrollo larvario. La administración in vivo de extracto acuoso a 62,1 mg / kg PC promovió una eficacia antihelmíntica del 54,57\% y, después de 14 días, no se observaron signos clínicos de toxicidad y cambios clínicos en los corderos tratados, lo que indica el potencial de este extracto para el control alternativa de la hemoncosis.

Palabras clave: Antihelmíntico; Buriti; Cerrado; Cromatografía de gases; Nematodos gastrointestinales; Oveja.

\section{Introduction}

One of the main limiting factors in sheep farming is the occurrence of gastrointestinal parasitosis caused by Haemonchus contortus. Sheep with haemonchosis present severe anemia and submandibular edema, and in more severe cases, mortality of parturient females and pups (Jackson et al., 2012). The frequent use of synthetic anthelmintics favors the selection of nematode strains that are resistant to the different groups of these drugs (Learmount et al., 2016). The use of plants extracts, such as Cocos nucifera from the Arecaceae family (Oliveira et al., 2009), have demonstrated anthelmintic in vivo efficacy, thus representing sustainable alternatives to the use of conventional anthelmintics.

Mauritia flexuosa L. f. - Arecaceae (buriti) is a non-deciduous palm tree found in Veredas (Ferreira, 2005). Oils extracted from this species fruits are mixed with other herbs and used in the skin diseases treatment (Paniagua-zambrana et al., 2015). However, this species anthelmintic potential in the alternative control of Haemonchus contortus is not known. In this perspective, the present study aimed to evaluate the in vitro and in vivo anthelmintic activity of M. flexuosa leaves on a Haemonchus contortus albendazole-resistant strain.

\section{Material and Methods}

\subsection{Collection area and extracts preparation}

Mauritia flexuosa leaves samples from young specimens (from six to ten meters height) were collected in October, 2016 (beginning of the rain season), in the most preserved area of the Água Doce vereda (15¹3'30" S 4455'04" W) localized in the Pandeiros Environmental Protection Area (EPA), Pandeiros river, Januária, Minas Gerais, Brazil. 
Damaged or deteriorated leaves were discarded, and the selected leaves were washed in running water, dehydrated in forced circulation ovens at $40^{\circ} \mathrm{C} \pm 5$ for 72 hours, and ground. The obtained powder was stored in a fresh and dark environment (Nery et al., 2010). Subsamples were used for dry matter (DM) determination, at $105^{\circ} \mathrm{C}$, to calculate the tested concentrations.

The aqueous (AE) and ethanolic (EE) extracts were obtained according to Nery et al. (2010). Both extracts were filtered in a gauze and cotton funnel and individually placed on a forced circulation oven at $40^{\circ} \mathrm{C}$ for three days. Extracts subsamples were used for $\mathrm{DM}$ determination, at $105^{\circ} \mathrm{C}$, and to obtain tannin-free extracts according to the method proposed by Nyman (1998).

\subsection{Extracts characterization and proanthocyanidins quantification}

For the derivatization procedure, extracts aliquots $(1.0 \mathrm{mg})$ measured in internally conical glass (suitable for this process), were dissolved in $60 \mu L$ pyridine and $100 \mu L$ BSTFA (N, O-Bis (trimethylsilyl) trifluoroacetamide) containing $1 \%$ chlorotrimethylsilane. The reaction mixture was heated at $60^{\circ} \mathrm{C}$ for $30 \mathrm{~min} .1 \mu \mathrm{L}$ of the obtained solution was injected into the Gas chromatography-mass spectrometry (GC-MS) in triplicates.

The chromatographic analysis was performed on a gas chromatograph (Agilent Technologies $\left(\mathrm{GC} 7890^{\mathrm{a}}\right)$ ) equipped with an electron-ionization detector (CG-EM) and DB-5MS capillary column (Agilent Technologies, $30 \mathrm{~m} \mathrm{long} \mathrm{x} 0.25 \mathrm{~mm}$ internal diameter x $0.25 \mu \mathrm{m}$ film thickness).

Helium (99.9999\% purity) was used as a carrier gas at $1 \mathrm{~mL} \mathrm{~min}^{-1}$. An auto-injector (CTC combiPaL) was used to inject $1 \mu \mathrm{L}$ of the sample into the chromatograph using 1:10 split ratio. The split/splitless injector was maintained at $290^{\circ} \mathrm{C}$. The chromatographic column, initially at $80{ }^{\circ} \mathrm{C}$, isothermal for five min., heated at $4{ }^{\circ} \mathrm{C} \mathrm{min}{ }^{-1}$ up to $260^{\circ} \mathrm{C}$ for 10 min. After the compounds separation, the temperature was elevated up to $300^{\circ} \mathrm{C}$ and maintained for 2 min. (post run). The interface temperature was maintained at $280{ }^{\circ} \mathrm{C}$, ionization performed by $70 \mathrm{eV}$ impact, and m/z scanning range from 30 to $600 \mathrm{Da}$.

The proanthocyanidins (condensed tannins) was quantified in the aqueous extract after acid-catalyzed solvolysis with n- $\mathrm{BuOH} / \mathrm{HCl} 37 \%$ (95:5), according to Hiermann et al., (1986). Following reaction with $n-\mathrm{BuOH} / \mathrm{HCl} 37 \%$ (95:5), the absorbance was read on a spectrophotometer at $540 \mathrm{~nm}$, being the values expressed as cyanidinium chloride.

\subsection{In vitro parasitological tests}

The experimental procedures were conducted according to the Ethics Committee on Animal Use of the Universidade Federal de Minas Gerais (CEUA-UFMG) and approved under the following protocol number: 275/2013.

\subsection{Hatchability test}

Three Santa Inês sheep, six to ten months old, were orally inoculated with 2,000 infective larvae (L3) of H. contortus albendazole-resistant strain (Duarte et al. 2012). After 28 days, $80 \mathrm{~g}$ of feces were collected directly from the rectal ampulla of each animal and transported to the laboratory. The Gordon \& Whitlock (1939) technique, modified by Ueno \& Gonçalves (1998), was used to quantify the eggs per gram of feces (EPG). Following an approximate 5 min rest period, the samples were evaluated under an optical microscope with a 10x objective lenses in duplicate.

For the in vitro evaluation of $H$. contortus larvae eclosion, the modified methodology proposed by the World Association for the Advancement of Veterinary Parasitology (WAAVP) according to Coles et al. (1992) to evaluate inhibition of hatchability was applied. The eggs were retrieved by the Bizimenyera et al. (2006) adapted methodology.

The extracts were diluted in sterile purified water to the following final concentrations: 75.0, 37.5, 18.9, and 9.4 mg/ml, $100 \mu \mathrm{L}$ of the extracts dilutions and approximately 100 eggs were placed in microdilution plates, $100 \mu \mathrm{L}$ of levamisole (Protall VP®, Vallée, Minas Gerais, Brazil) $(0.3 \mathrm{mg} / \mathrm{mL})$ and was used as positive control and $100 \mu \mathrm{L}$ of sterile water as negative control. 
The plates were homogenized, covered with plastic film and incubated in BOD oven at $28^{\circ} \mathrm{C}$ for $72 \mathrm{~h}$. Following this period, 100 $\mu \mathrm{L}$ of formaldehyde $10 \%$ (v/v) was added, and the plates were stored at $4^{\circ} \mathrm{C}$, to avoid fungi proliferation.

The quantification of blastomerate eggs, larval eggs and first-instar larvae (L1) were performed in an optical microscope with the 10x objective lens. The experiment was performed with five replicates per treatment, in a completely randomized design. The mean hatchability inhibition efficiency was calculated by the Coles et al. (1992) adapted formulae: $\%$ Efficiency $=100 \times[1-(\mathrm{L} 1 /$ initial eggs number $)]$.

In the hatchability test, the number of L1 and eggs not hatched was converted into values relative to the initial amount in each replicate. The data obtained were submitted to the variance and means analysis, compared by the Tukey post-hoc test with $5 \%$ probability and probit regression analysis was applied to determine the concentration to inhibit 90\% (LC90) of hatchability, using the SAEG® 9.1 (2007) statistical package.

\subsection{Larval development inhibition (LDI)}

The larval development inhibition test was performed according to Nery et al., (2010), adapted by Borges (2003), by the distribution of $2 \mathrm{~g}$ of homogenized feces in disposable cups, and the extract $(2 \mathrm{~g}$ of extract powder or $2 \mathrm{~mL}$ of aqueous or ethanolic extract). Two mL of solution containing levamisole (Protall VP®, Vallée, Minas Gerais, Brazil) at 0.3 mg/mL was used as positive control and $2 \mathrm{~mL}$ of sterile purified water as negative control.

In the coproculture, concentrations from 38.02 to $304 \mathrm{mg} / \mathrm{g}$ of M. flexuosa pure leaf powder were evaluated. For the AE, concentrations from 0.8 to $12.83 \mathrm{mg} / \mathrm{g}$ were evaluated. The efficiencies were assessed via the Borges (2003) adapted formula:

$\%$ Efficiency $=100 \times$ (1- the number of third-stage larvae recovered per gram of feces (LPG) from the treated group / LPG from the negative control group).

For the statistical analysis, the LPG number was transformed via the $Y=\log (x+10)$ equation, submitted to the variance analysis and compared by the Duncan test, considering the significance level at $5 \%$. The probit regression analysis was performed to determine the concentration to inhibit $90 \%$ of the larval development, following a 7-day incubation period. All analyses were conducted in the SAEG® 9.1 (2007) statistical package.

\subsection{In vivo analysis}

The extracts effect of reducing the number of eggs in the feces was evaluated in twelve Santa Inês lambs (6 male and 6 female), five to six months old, weighing in average $25.5 \mathrm{Kg}$. During the 14-days adaptation period, the animals were individually confined and fed a diet containing sorghum silage, concentrate, mineral premix, and water ad libitum. The lambs presenting zero EPG in two counting procedures were infected with $800 \mathrm{H}$. contortus L3 (infective larvae as reported above) per $10 \mathrm{~kg}$ of body weight.

Twenty-eight days after infection, the lambs were divided into two homogeneous groups based on EPG, weight, and gender ( 3 male and 3 female per group). One group with non-treated lambs represented the negative control, and the other group was treated with $61.2 \mathrm{mg}(\mathrm{ms}) / \mathrm{Kg} / \mathrm{BW}$ of $M$. flexuosa leaves extract dissolved in water and administrated via esophageal probe for two consecutive days. The dosage was based on the LC90 estimated by the larval development inhibition test (Morais-Costa et al., 2016; Caldeira et al., 2019a; Caldeira et al., 2019b). The treatment was conducted in the morning, after a 12-h fasting period and the animals were monitored for any signs of behavioral and clinical alterations. The animals were weighted before feeding in the $7^{\text {th }}$ and $14^{\text {th }}$ days after treatment.

The EPG was evaluated three times with weekly intervals. Each period covered in average three days, where daily means were obtained, totalizing six EPG measurements per animal (Morais-Costa et al., 2016). The EPG means were registered 
two days before the treatment and at the administration day. Posteriorly, the mean EPG was calculated in days 7, 8 and 9 (second period); Days 14, 15 and 16 (third period). The MacMaster technique was performed with saturated $\mathrm{NaCl}$ and a minimum sensitivity of $25 \mathrm{eggs} / \mathrm{g}$ of feces (Gordon e Whitlock, 1939). The treatment efficiency was calculated by the following formula adapted from Coles et al. (1992):

$\%$ EPG reduction $=100 \times[1-($ mean EPG per treated group $/$ mean EPG per non-treated group $)$.

The obtained EPG data was transformed into $\log 10(\mathrm{x}+10)$ and submitted to variance analysis in the two evaluated periods. The means were compared by the Scott-Knott test $(P<0.05)$.

\section{Results}

\subsection{Extracts characterization}

Mauritia flexuosa AE and EE chemical composition was determined by chromatographic analysis, where fifteen and ten major compounds were identified in $M$. flexuosa leaves AE and EE, respectively, and all extracts presented catechins peaks (Figure 1 e 2 ). The total proanthocyanidin value calculated via spectrometry was $33.23 \pm 2 \%$ for $M$. flexuosa aqueous extract.

Figure 1. Aqueous extract gas chromatography of the leaves of Mauritia flexuosa.

\section{Abrdare}

\section{TICक62016 AGR1.Ddans}

1.400

12007

1e10

800000

600000

400000

200000

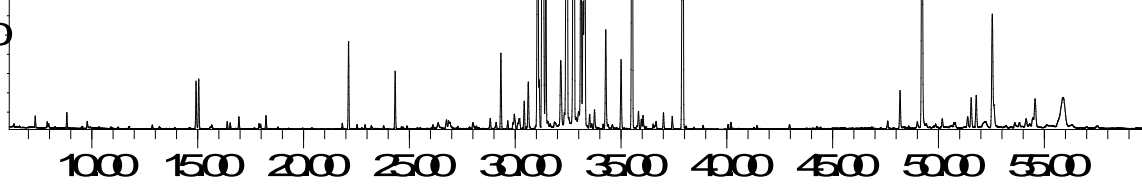

Source: Authors (2020). 
Figure 2. Ethanolic extract gas chromatography of the leaves of Mauritia flexuosa.

\section{Aardare}

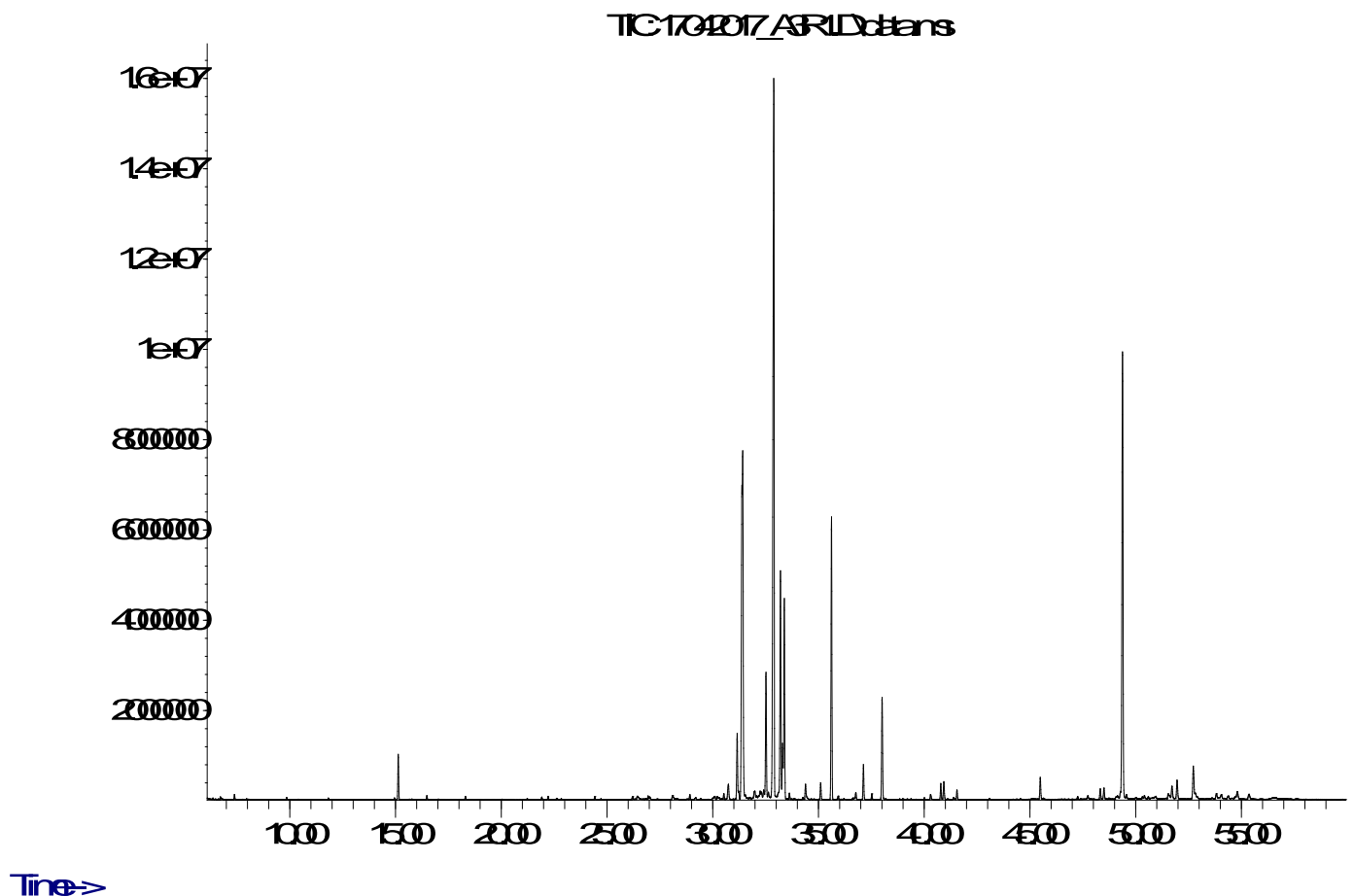

Source: Authors (2020).

Respectively in Figure 1 and 2, the AE and EE presented catechins in the following retention times: $54.56(0.47 \%$ area) and $54.81(0.26 \%$ area $) \mathrm{min}$.

In the AE, the major compounds were: glucopyranoside (6.48\%), glucitol (14.24\%), inositol (10.34\%) and a few nonidentified carbohydrates (25.27\%), however, for the EE, the main compound was d-fructose (18.59\%), especially the glucopyranoside (16.24\%) (Table 1). 
Table 1. Percentage of the main compounds identified by gas chromatography in leaf extracts of Mauritia flexuosa.

\begin{tabular}{|c|c|c|c|c|c|c|c|}
\hline \multicolumn{4}{|c|}{ Aqueous Extract } & \multicolumn{4}{|c|}{ Ethanol Extract } \\
\hline Peak & RT & Compounds & Area (\%) & Peak & RT & Compounds & Area $(\%)$ \\
\hline 1 & 14.923 & Phosphate & 0.56 & 1 & 15.129 & Glycerol & 1.11 \\
\hline 2 & 22.128 & DL-malic acid & 1.02 & 2 & 31.416 & D-fructose & 18.59 \\
\hline 3 & 24.330 & Thraionic acid & 0.70 & 3 & 32.888 & Carbohydrate N.I. & 30.26 \\
\hline 4 & 31.287 & Carbohydrate N.I. & 11.56 & 4 & 35.616 & Glycopyranose isomer & 7.73 \\
\hline 5 & 31.449 & Isocystric acid & 2.06 & 5 & 37.124 & Hexadecanoic acid & 0.93 \\
\hline 6 & 31.067 & D-fructose & 6.55 & 6 & 38.008 & Isosorbide of Inosiol & 2.92 \\
\hline 7 & 32.457 & Carbohydrate N.I. & 13.71 & 7 & 41.548 & Octadecanoic acid & 0.23 \\
\hline 8 & 32.787 & Glucitol & 14.24 & 8 & 45.487 & 12-hydroxyoctadecanoic acid & 0.52 \\
\hline 9 & 34.158 & D-mannitol & 0.05 & 9 & 49.377 & Glicopyranoside & 16.84 \\
\hline 10 & 35.529 & Talose & 8.83 & 10 & 54.810 & Catechin & 0.22 \\
\hline 11 & 37.920 & Inositol & 10.34 & & & & \\
\hline 12 & 49.222 & Glicopyranoside & 6.48 & & & & \\
\hline 13 & 52.541 & Carbohydrate N.I. & 2.23 & & & & \\
\hline 14 & 51.545 & 2,5-dihydroxybenzoic acid & 0.42 & & & & \\
\hline 15 & 54.569 & Catechin & 0.39 & & & & \\
\hline
\end{tabular}

RT - Retention time (min). N.I. - Not identified. Source: Authors (2020).

Gas chromatography analysis indicated the presence of fifteen and ten major compounds in the aqueous and ethanolic extracts, respectively, and both showed catechin peaks.

\subsection{In vitro anthelmintic activity}

Mauritia flexuosa $\mathrm{AE}$ and EE at $75 \mathrm{mg} / \mathrm{mL}$ presented $100 \%$ of anthelmintic activity in the hatchability test, and over $90 \%$ at $37.5 \mathrm{mg} / \mathrm{mL}$, with statistically significant differences as compared to the negative control (sterile water) $(P<0.05)($ Table 2). The LC90 for M. flexuosa leaves AE and EE were, respectively, $21.8 \pm 3$ and $8.5 \pm 3 \mathrm{mg} / \mathrm{ml}$.

The tannin-free EE presented $61.5 \%$ efficiency at $75 \mathrm{mg} / \mathrm{ml}$, which is comparatively lower than the EE with tannins efficiency at the same concentration (Table 2). 
Table 2. Efficacy of aqueous and ethanolic extracts, with and without tannin, of Mauritia flexuosa leaves for inhibition of Haemonchus contortus hatchability.

\begin{tabular}{|c|c|c|c|c|c|}
\hline Treatments & Blastomerate egg & Larval egg & L1 (Larvae) & Eggs + L1 & Efficiency* $(\%)$ \\
\hline \multicolumn{6}{|l|}{ With tannins } \\
\hline \multicolumn{6}{|l|}{ Mauritia flexuosa } \\
\hline \multicolumn{6}{|l|}{ Aqueous Extract $\left(\mathrm{mg} \mathrm{mL}^{-1}\right)$} \\
\hline 75.0 & $0.0^{\mathrm{e}}$ & $0.0^{\mathrm{a}}$ & $0.0^{\mathrm{f}}$ & 0 & 100.0 \\
\hline 37.5 & $2.6^{\mathrm{d}}$ & $4.0^{\mathrm{b}}$ & $4.8^{\mathrm{f}}$ & 11.4 & 93.21 \\
\hline 18.8 & $16.0^{\mathrm{f}}$ & $10.6^{\mathrm{h}}$ & $9.0^{\mathrm{a}}$ & 35.6 & 87.27 \\
\hline 9.4 & $19.6^{\mathrm{f}}$ & $17.2^{\mathrm{h}}$ & $17.4^{\mathrm{a}}$ & 54.2 & 75.40 \\
\hline \multicolumn{6}{|l|}{ Ethanol extract $\left(\mathrm{mg} \mathrm{mL}^{-1}\right)$} \\
\hline 75.0 & $0.0^{\mathrm{e}}$ & $0.0^{\mathrm{g}}$ & $0.0^{\mathrm{b}}$ & 0.0 & 100.0 \\
\hline 37.5 & $4.4^{\mathrm{c}}$ & $3.6^{\mathrm{e}}$ & $3.6^{\mathrm{d}}$ & 11.6 & 94.91 \\
\hline 18.8 & $4.6^{\mathrm{c}}$ & $5.8^{\mathrm{f}}$ & $4.8^{\mathrm{c}}$ & 15.2 & 93.21 \\
\hline 9.4 & $5.6^{\mathrm{b}}$ & $6.6^{\mathrm{d}}$ & $5.4^{\mathrm{e}}$ & 17.6 & 92.36 \\
\hline \multicolumn{6}{|l|}{ Without Tannins } \\
\hline \multicolumn{6}{|l|}{ Mauritia flexuosa } \\
\hline \multicolumn{6}{|l|}{ Aqueous Extract $\left(\mathrm{mg} \mathrm{mL}^{-1}\right)$} \\
\hline 75.0 & $1.0^{\mathrm{e}}$ & $31.8^{\mathrm{a}}$ & $0.0^{\mathrm{f}}$ & 32.8 & 100.0 \\
\hline 37.5 & $3.4^{\mathrm{d}}$ & $30.4^{\mathrm{b}}$ & $0.0^{\mathrm{f}}$ & 33.8 & 100.0 \\
\hline 18.8 & $0.0^{\mathrm{f}}$ & $0.0^{\mathrm{g}}$ & $31.8^{\mathrm{a}}$ & 31.8 & 55.05 \\
\hline 9.4 & $0.0^{\mathrm{f}}$ & $0.0^{\mathrm{g}}$ & $40.8^{\mathrm{a}}$ & 40.8 & 42.33 \\
\hline \multicolumn{6}{|l|}{ Ethanol extract $\left(\mathrm{mg} \mathrm{mL}^{-1}\right)$} \\
\hline 75.0 & $1.6^{\mathrm{e}}$ & $7.2^{\mathrm{f}}$ & $39.4^{\mathrm{b}}$ & 39.4 & 61.5 \\
\hline 37.5 & $5.6^{\mathrm{c}}$ & $10.6^{\mathrm{d}}$ & $27.2^{\mathrm{d}}$ & 43.4 & 56.7 \\
\hline 18.8 & $6.8^{c}$ & $11.6^{\mathrm{e}}$ & $34.8^{\mathrm{c}}$ & 53.2 & 50.8 \\
\hline 9.4 & $10.8^{\mathrm{b}}$ & $17.4^{\mathrm{cd}}$ & $38.6^{\mathrm{e}}$ & 66.8 & 45.4 \\
\hline Levamisol phosphate $\left(0.3 \mathrm{mg} \mathrm{mL}^{-1}\right)$ & $45.4^{\mathrm{a}}$ & $18.2^{\mathrm{c}}$ & $0.0^{\mathrm{f}}$ & 63.6 & 100.0 \\
\hline Sterile distilled water & $0.0^{\mathrm{f}}$ & $0.0^{\mathrm{h}}$ & $70.7^{\mathrm{a}}$ & 70.7 & - \\
\hline Coefficient of variation $(\%)$ & 9.7 & 4.19 & 1.9 & & \\
\hline
\end{tabular}

Different letters in the columns indicate a significant difference $(P<0.05)$ by Tukey test at $5 \%$.

$* \%$ efficacy $=100 \times(1-$ L1 / initial egg numbers). Source: Authors (2020).

Mauritia flexuosa tannin-free AE LC90 was $25.48 \mathrm{mg} / \mathrm{ml}$. It was not possible to calculate the tannin-free EE $90 \%$ lethal concentrations due to its low efficiency.

Mauritia flexuosa powder from dehydrated leaves at $304 \mathrm{mg} / \mathrm{g}$ of coproculture, presented $86.54 \%$ of anthelmintic efficiency for LDI (Table 3) and differed statistically from the control with sterile water $(P<0.05)$. The AE at the highest concentration $(12.83 \mathrm{mg} / \mathrm{g}$ ) was $53 \%$ effective to inhibit larval development (Table 3 ). 
Table 3. Efficacy of crushed leaves (powder) and aqueous extract of M. flexuosa to inhibit the development of Haemonchus contortus larvae.

\begin{tabular}{lll}
\hline Treatments (mg / g) & LPGF* $^{*}$ & Efficiency (\%) \\
\hline Crushed leaves (powder) & & \\
Mauritia flexuosa & $138.0^{\mathrm{f}}$ & 86.54 \\
304.0 & $188.0^{\mathrm{ef}}$ & 81.65 \\
228.12 & $200.0^{\mathrm{ef}}$ & 80.43 \\
152.08 & $213.0^{\text {def }}$ & 79.20 \\
76.04 & $253.0^{\mathrm{de}}$ & 75.29 \\
38.02 & & \\
& & \\
Aqueous extract & & 53.52 \\
Mauritia flexuosa & $475.0^{\mathrm{d}}$ & 35.17 \\
12.83 & $663.0^{\mathrm{c}}$ & 33.95 \\
6.41 & $675.0^{\mathrm{c}}$ & 11.93 \\
3.20 & $900.0^{\mathrm{b}}$ & 9.49 \\
1.60 & $925.0^{\mathrm{b}}$ & --- \\
0.80 & $1187.0^{\mathrm{a}}$ & 100.0 \\
Sterile distilled water & $0.0^{\mathrm{g}}$ & \\
Levamisol phosphate $(0.3 \mathrm{mg} / \mathrm{ml})$ & & \\
\hline
\end{tabular}

Different letters indicate significant difference by the Duncan test $(P<0.05)$

Coefficient of variation LDI: $0.98 \%$.

* LPGF: number of infective larvae per gram of faeces in coproculture.

Efficacy: \% efficacy $=100 \times$ ( 1 - LPGF of the treated group / LPGF of the control group).

Source: Authors (2020).

\subsection{In vivo anthelmintic activity}

Following 14 days of AE administration, the EPG in the treated group was significantly decreased as compared to the non-treated group, displaying a 54.57\% efficiency and 37.5\% variation coefficient (Table 4). Additionally, clinical signs of toxicity in the mucosas or animals behavior were not observed.

Table 4. Mean OPG of treated sheep after oral administration of aqueous extracts of Mauritia flexuosa leaf at $62.1 \mathrm{mg}$ $(\mathrm{ms}) / \mathrm{kg} / \mathrm{bw}$.

\begin{tabular}{lllllll}
\hline Treatments & Day 0 & Day 7 & Efficiency $(\%)$ & Day 14 & Efficiency (\%) & Average \\
\hline Control & 887 & $875 \mathrm{Ab}$ & -- & $908 \mathrm{Aa}$ & -- & $891.5 \mathrm{~A}$ \\
M. flexuosa & 795 & $760 \mathrm{Aa}$ & $13.14 \%$ & $410 \mathrm{Ab}$ & $54.57 \%$ & $585.0 \mathrm{~B}$ \\
\hline
\end{tabular}

Different upper case letters in the column and lowercase in the row indicate statistical differences by the Scott-Knott test $(P<0.05)$.

Efficacy $=100 \times(1-$ OPG mean of treated group / mean OPG of control group $)$.

Coefficient of variation $=37.5 \%$. Source: Author's (2020).

\section{Discussion}

The verminosis have a negative impact on the animal's production, being the main responsible limiting factor to hinder the animal's maximum productive performance (Vieira et al., 2014). The most commonly used measure in the verminosis control is the administration of chemical anthelmintic products, which, besides increasing the production costs, favor the appearance of 
parasites resistant to the main products available (Learmount et al., 2016). In study, of Aboelhadid et al. (2021), was detected at $H$. contortus, which was susceptible to levamisole and ivermectin, had developed resistance to albendazole. Field populations of this species show resistance to all major anthelmintic drug classes, including benzimidazoles, imidazothiazoles and macrocyclic lactones (Kotze \& Prichard, 2016).

In the present study, M. flexuosa leaves presented $100 \%$ anthelmintic efficiency to inhibit hatchability with both extracts (AE and EE) at $75 \mathrm{mg} / \mathrm{ml}$. However, the EE displayed better results, because in the lowest concentration $(9.4 \mathrm{mg} / \mathrm{ml}) \mathrm{presented}$ 92.36\% efficiency, while the AE in the same concentration presented only $75.4 \%$ efficiency (Table 2). Oliveira et al., (2009) reported in a study performed with a palm tree from the same family as buriti (Arecaceae), that the EE from the fruits peels presented $100 \%$ efficiency at $5.1 \mathrm{mg} / \mathrm{ml}$.

The tests performed with the tannin-free extracts evidenced a decreased anthelmintic effect on the hatchability inhibition for the ethanolic extract, but for the aqueous extract, this reduction was only observed for the lowest concentrations, indicating that the tannins are not the only responsible for the inhibition of hatchability, as suggested by Morais-Costa et al. (2016). Although $M$. flexuosa have increased amounts of total tannins (33.23\%), higher than the values displayed for $C$. nucifera (25.87\%) Oliveira et al., (2009), these compounds removal did not inhibit completely the anthelmintic effect, suggesting that the presence and/or combination of other secondary metabolites in the plant, such as catechins, flavonoids, and amino acids may contribute to the anthelmintic activity, as proposed by Klongsiriwet et al. (2015).

In our study, M. flexuosa leaves AE oral administration presented a moderate efficiency, however, these results are promising considering that the administered dosage $(62.1 \mathrm{mg} / \mathrm{kg} / \mathrm{pc})$ was low and applied only twice. In another study that used a higher dosage of Piptadenia viridiflora AE $(283 \mathrm{mg} / \mathrm{kg} / \mathrm{pc})$, the authors reported a $47.2 \%$ EPG reduction in the first week and $32.9 \%$ in the third week, after 21 days of treatment (Morais-Costa et al., 2016).

\section{Conclusion}

Mauritia flexuosa AE and EE presented increased tannins levels, and the chromatographic analysis revealed the presence of catechins. These extracts were effective to inhibit $H$. contortus eggs hatchability and larval development. A moderate anthelmintic efficiency was observed when M. flexuosa AE was applied in vivo and the animals did not display any clinical signs of toxicity. It is necessary that bioactive compounds from $M$. flexuosa are isolated and tested. In this perspective, the present findings highlight the potential of $M$. flexuosa leaves in the alternative control of this nematode in ruminants.

\section{Conflicts of interest}

The authors of this manuscript have no financial or personal relationships with individuals or organizations that may influence this manuscript content.

\section{Acknowledgement}

The present study was performed and supported by the Coordenadoria de Aperfeiçoamento do Pessoal de Nível Superior (CAPES) (grant 001), Conselho Nacional de Desenvolvimento Científico (CNPQ), Fundação de Amparo à Pesquisa do Estado de Minas Gerais (FAPEMIG), Universidade Estadual de Montes Claros (UNIMONTES), and Universidade Federal de Minas Gerais (UFMG). 


\section{References}

Aboelhadid, S. M., Arafa, W. M., El-Ashram, S. Noaman, A. F., Shokier, K. A., Darwish, A. B., Mahmoud, M. M. \& Gadelhaq, S. M. (2021). Haemonchus contortus Susceptibility and Resistance to Anthelmintics in Naturally Infected Egyptian Sheep. Acta Parasitologica 66, 329 - 335. https://doi.org/10.1007/s11686-020-00284-1.

Bizimenyera, E. S., Githiori, J. B, Eloff, J. N. \& Swan, G. E. (2006). In vitro activity of Peltophorum africanum Sond. (Fabaceae) extracts on the egg hatching and larval development of the parasitic nematode Trichostrongylus colubriformis. Veterinary Parasitolology 142, 336-343.

Borges, C. C. L. (2003). Atividade in vitro de anti-helmínticos sobre larvas infectantes de nematódeos gastrintestinais de caprinos, utilizando a técnica de coprocultura quantitativa (Ueno, 1995). Parasitolology Latin American 58, 142 -147.

Caldeira, M. A. M., Morais-Costa, F., Macêdo, K. M., Martins Júnior, V. S., Pereira, D. E. A., Soares, A. C. M., Martins, I. P., Lopes, I. M. G., Braga, F. C., Oliveira, N. J. F. \& Duarte, E. R. (2019a). Anthelmintic activity of Annona crassiflora leaves against Haemonchus contortus: part 1: in vitro inhibition of the hatchability and larval development. Medicina Veterinária (UFRPE) 13(2), 184-191. https://doi.org/10.26605/medvet-v13n2-3067.

Caldeira, M. A. M., Morais-Costa, F., Macêdo, K. M., Martins Júnior, V. S., Pereira, D. E. A., Soares, A. C. M., Martins, I. P., Lopes, I. M. G., Braga, F. C., Oliveira, N. J. F. \& Duarte, E. R. (2019b). Anthelmintic activity of Annona crassiflora leaves against Haemonchus contortus: part 2: efficacy in vivo and blood parameters. Medicina Veterinária (UFRPE) 13(2), 192-198. https://doi.org/10.26605/medvet-v13n2-3068.

Coles, G. C, Bauer, C., Borgsteede, F. H., Geerts, S., Klei, T. R., Taylor, M. A. \& Waller, P. J. (1992). World Association for the Advancement of Veterinary Parasitology (WAAVP) - Methods for detection of anthelmintic resistance in nematodes of veterinary importance. Veterinary Parasitolology 44, 35-44.

Duarte, E. R., Silva, R. B., Vasconcelos, V. O., Nogueira, F. A., \& Oliveira, N. J. F. (2012). Diagnóstico do controle e perfil de sensibilidade de nematoides de ovinos ao albendazol e ao levamisol no norte de Minas Gerais. Pesquisa Veterinária Brasileira, 32, 147-152.

Ferreira, I. M. (2005). Bioma Cerrado: caracterização do subsistema de vereda. In: Encontro Regional De Geografia: Novas territorialidades, integração e redefinição regional, 14, 2005, Porto Nacional, Anais.

Gordon, H. M. \& Whitlock, H. V. (1939). A new technique for counting nematode eggs in sheep faeces. Journal of the Council for Scientific and Industrial Research $12,50-52$.

Hiermann, A., Kartnig, T.H., \& Azzam, S. (1986). Ein beitrag zur quantitativen bestimmung der procyanidine in crataegus. Scientia Pharmaceutica 54, 331337.

Jackson, F., Varady, M., \& Bartley, D. J. (2012). Managing anthelmintic resistance in goats: can we learn lesson from sheep? Small Ruminant Research 103, 3 9 .

Klongsiriwet, C., Quijada, J., Williams, A. R., Mueller-Harvey, I., Williamson, E. M., \& Hoste, H. (2015). Synergistic inhibition of Haemonchus contortus exsheathment by flavonoid monomers and condensed tannins. International Journal for Parasitology Drugs and Drug Resistance 5, $127-134$.

Kotze, A. C., \& Prichard, R. K. (2016). Anthelmintic Resistance in Haemonchus contortus: History, Mechanisms and Diagnosis. Advances in Parasitology 93, 397-428. https://doi.org/10.1016/bs.apar.2016.02.012.

Learmount, J., Sthephens, N., Boughtflower, V. \& Barrecheguren, A. (2016). The development of anthelmintic resistance with best practice control of nematodes on commercial sheep farms in the UK. Veterinary Parasitolology 229, 9-14.

Morais-Costa, F., Bastos, G.A., Soares, A. C. M., Costa, E. G. L., Vasconcelos, V. O., Oliveira, N. J. F., Braga, F. C., Duarte, E. R. \& Lima, W. S. (2016). In vitro and in vivo action of Piptadenia viridiflora (Kunth) Benth against Haemonchus contortus in sheep. Veterinary Parasitolology $223,43-49$.

Nery, P. S, Nogueira, F. A, Martins, E. R. \& Duarte, E. R. (2010). Effect of Anacardium humile on the larval development of gastrintestinal nematodes of sheep. Veterinary Parasitolology 171, 361-364.

Nyman, U., Joshi, P., Madsen, L. B., Pinstrup, M., Rajasekharan, S., George, V. \& Pushpangadan, P. (1998). Ethnomedical information and in vitro screening forangiotensin-converting enzyme inhibition of plants utilized as traditionalmedicines in Gujarat, Rajasthan and Kerala (India). Journal of Ethnopharmacology $60,247-263$.

Oliveira, L. M. B., Bevilaqua, C. M. L., Costa, C. T. C, Macedo, I. T. F, Barros, R. S., Rodrigues, A. C. M., Camurça-Vasconcelos, A. L. F., Morais, S. M., Lima, Y. C., Vieira, L. S., \& Navarro, A. M. C. (2009). Anthelmintic activity of Cocos nucifera L. against sheep gastrointestinal nematodes. Veterinary Parasitolology 159, 55-59.

Paniagua-Zambrana, N., Cámara-Leret, R. \& Macía, M. J. (2015). Patterns of Medicinal Use of Palms Across Northwestern South America. The Botanic Review $81,317$.

Ueno, H. \& Gonçalves, P. C. 1998. Manual para diagnóstico das helmintoses de ruminantes. Japan International Cooperation Agency.

Vieira, V. D., Feitosa, T. F., Vilela, V. L. R, Azevedo, S. S., Almeida Neto, J. L., Morais, D. F., Ribeiro, A. R. C. \& Athayde, A. C. R. (2014). Prevalence and risk factors associated with goat gastrointestinal helminthiasis in the Sertão region of Paraíba State, Brazil. Tropical Animal Health Producion 46, 355-361. 